\title{
RESENHA
}

DOI: http://dx.doi.org/10.1590/So034-759020170411

\section{DISCURSO E PRÁTICA DO MARKETING: UMA PERSPECTIVA CRÍTICA}

MARKETING DISCOURSE: A CRITICAL PERSPECTIVE

De Per Skålén, Martin Fougère, \& Markus Fellesson. London, UK: Routledge, 2012. 190 p.

Nesta obra, os autores propõem uma análise crítica do discurso do marketing, destacando o desenvolvimento do gerencialismo no discurso acadêmico, já que uma das preocupações centrais da teoria da gestão tem sido a busca da eficiência e eficácia, e sua inter-relação com o poder. 0 gerencialismo da teoria do marketing é produzido e reproduzido por meio do discurso de servir o cliente e o mercado, discutido pelos autores por intermédio do conceito do customerismo. 0 livro traz uma visão crítica e histórica do papel ideológico e formativo do marketing no discurso gerencial, apoiado no crescimento da cultura de mercado e do neoliberalismo, que permeiam atualmente as organizações públicas e privadas. Dado que o poder discursivo baseado no conhecimento não é visto como uma forma de poder pela maioria das pessoas, a obra pode despertar seus leitores para uma análise crítica, sejam eles alunos de graduação, de programas de pós-graduação ou docentes.

Embora o livro tenha sido publicado em 2012, faz parte do debate atual. Cabe ressaltar a experiência dos autores desta obra em países escandinavos, que, da mesma forma que outros pesquisadores das escolas nórdicas, como Kjeldgaard e Askegaard, destacam-se nesse debate, que ultrapassa as correntes principais de gestão e marketing norte-americanas. Outros autores corroboram a análise crítica, tais como: Brownlie, Saren, Wensley, e Whittington, em Rethinking marketing: Towards critical marketing accountings (1998), da editora Sage, assim como Saren, Maclaran, Goulding, Elliott e Caterall, na obra Critical marketing (2012), da editora Routledge.

A apresentação dos fatos pelos autores segue uma sequência lógica nos capítulos: a pesquisa crítica em marketing; a noção de poder/conhecimento, governamentalidade e governo; a análise do discurso governamental; a introdução do conceito de poder/conhecimento no marketing gerencial, sua consolidação e posterior elaboração; e, por fim, a crítica ao customerismo.

Primeiramente, apresentam-se importantes implicações do marketing na atual gestão das organizações, abordando o papel de seus membros e clientes. Por meio de um enfoque histórico do marketing, os autores fundamentam sua posição crítica, ba- 
seando-se em trabalhos de Foucault e Morgan, e nos conceitos de poder, conhecimento, discurso e governamentalidade. Esse termo, derivado de governo e mentalidade, estabelece uma perspectiva à parte do poder estatal e da ideologia das práticas de governo. Os autores discutem como tais práticas se desenvolvem, apresentam suas formas, tecnologias, saberes, poderes e estratégias correspondentes ao seu desenvolvimento no mundo prático. De Foucault, os autores também extraem a forte relação entre o discurso e sua subjetividade, já que ele não se fundamenta em atributos estáveis, como as crenças, valores, motivações e experiência dos indivíduos. Já no tocante ao discurso acadêmico de marketing, duas perspectivas emergem, prescrevendo uma determinada orientação: questões relativas à compreensão das escolhas dos consumidores e da percepção do marketing como parte do discurso de gestão.

A obra também apresenta uma ligação histórica dos primórdios do marketing (início do século XX) com as obras dos economistas clássicos, neoclássicos e da moderna economia, dado que professores formados pela Escola Histórica Alemã de Economia foram os precursores das cadeiras de marketing.

Já ao analisarem os estudos de Morgan daquela época, evidenciam uma perspectiva crítica de luta contra os grandes negócios. Mas, com o acirramento do ambiente competitivo a partir dos anos 1930, a orientação geral começa a se voltar para a o cliente. Entre 1930-1960, segundo os autores, dá-se o refinamento do dito gerencialismo do marketing, período no qual a Academia de Marketing norte-americana (AMA) tem papel preponderante na elaboração do discurso. 0 marketing, então, se concentra na tentativa de implantar os conceitos da administração cientifica de Taylor para a gestão de equipes de vendas, buscando impor essa mesma racionalidade para o gerenciamento de cada função organizacional. Essa tendência atinge seu pico no final dos anos 1950, com o lançamento do conceito de marketing, no qual não seriam mais as empresas o centro do universo empresarial, mas sim o cliente. A atenção desloca-se dos problemas de produção para problemas de comercialização - ou marketing. Em paralelo, dá-se também a emergência das grandes multinacionais e da doutrina anticomunista da Guerra Fria. Naquela época, os estudiosos de marketing também desempenham um importante papel na definição dos conhecimentos práticos, articulando e fixando significados dos diferentes termos. Eles criam uma língua geral dentro de um discurso coerente, privilegiando o conhecimento prático e consolidando-o como conhecimento acadêmico a ser transferido para futuras gerações de profissionais de marketing.

Já a partir de 1990, com o advento da pós-modernidade conceito da sociologia histórica que denota a condição socio- cultural e estética prevalente no capitalismo após a queda do Muro de Berlim - dá-se a dissolução da referência à razão como uma garantia de possibilidade de compreensão do mundo por meio de esquemas totalizantes. Essa concepção, assumida por filósofos como Lyotard e Baudrillard, sustenta reflexões acadêmicas sobre a desintegração dos mercados de massa e gera interesse nas áreas do micro-marketing, database marketing e marketing one-on-one, além da hiper-realidade, exemplificadas no livro pelos estudos de shopping centers e parques temáticos e pelas investigações de tempo/percepção. Ocorrem também mudanças de perspectiva das organizações, das relações com o exterior das empresas para as relações internas, do setor privado para o setor público, do cognitivo para o emocional, de cuidar do cliente para conhecer o cliente, e de questões ideológicas do discurso, sob influência do neoliberalismo e da orientação para o cliente.

Segundo os autores, na academia, a produção de conhecimento é enquadrada por limites tradicionais estreitos que não permitem explorar perspectivas alternativas, o que se manifesta, por exemplo, nas dificuldades em se publicarem estudos de marketing crítico em periódicos. Estratégias retóricas, presentes em textos britânicos e norte-americanos, denotam um estilo normativo, não reflexivo, com estilo de consultorias de gestão, e baseado em conceitos centrais, construído para ser de fácil consumo na educação e treinamento dos executivos. A distorção e simplificação geram a legitimação. A doutrina do marketing, portanto, reforça os paradigmas de que, numa economia de mercado, tudo o que é benéfico para o indivíduo é também benéfico para a sociedade, e de que um dos critérios para o bem comum é o crescimento geral da riqueza, quem quer que seja o beneficiário. Além disso, uma economia de mercado livre e próspera fomenta a liberdade e a democracia.

A obra se encerra relatando a relação entre o discurso e a prática do marketing acadêmico. Os autores mencionam o controle da expressão de emoções e valores dos funcionários, e sua comercialização para o "melhor atendimento dos clientes". Nesse contexto, a empresa deveria treinar seus funcionários a serem felizes e a sorrirem no ato de prestação de serviços.

Do ponto de vista estrutural, o livro tem um encadeamento lógico que permite compreender o contexto global do discurso de marketing. A apresentação de uma trajetória histórica, a qual fornece alicerces para uma análise crítica ao modelo estabelecido, é uma de suas principais contribuições. No entanto, uma crítica não realizada na obra refere-se ao discurso econômico vigente da economia de mercado, em que poderiam ser abordadas questões de macro-marketing, relativas aos impactos socioambientais globais, práticas de consumo e de mercado da sociedade pós-moderna. 